\title{
Quinoline as TRPV1 Antagonists: A New Approach against Inflammation
}

\author{
* Megha P. Ambatkar, Pramod B. Khedekar \\ Department of Pharmaceutical Sciences, Rashtrasant Tukadoji Maharaj Nagpur University, Nagpur- 440 033. Maharashtra, India
}

\begin{abstract}
Inflammation is the first response of the immune system to harmful stimuli such as infection or irritation, consists of a cascade of biochemical events that propagates and matures the inflammatory response. Numbers of anti-inflammatory drugs are available for treatment of acute and chronic inflammation. Many anti-inflammatory drugs cause adverse side effects. The quinoline class of compounds are important for searching the safe and effective anti-inflammatory drugs. These drugs are classified based on the number of substituents present on the quinoline ring or compounds containing a quinoline ring fused to other heterocyclic compounds. Quinolines have the ability to target several causes of inflammation includes transient receptor potential vanilloid 1 receptor. The TRPV1 receptor, first cloned and characterized in 1997, is a nonselective cation channel expressed in primary sensory neurons, and is a key pain sensor and integrator. This review provides the discovery of various quinoline derivatives as transient receptor potential vanilloid 1 (TRPV1) antagonists. Overall, the quinoline moiety will be used as a new template for designing and identifying the novel anti-inflammatory drugs in future.
\end{abstract}

Keywords: Quinoline, Inflammation, Transient receptor Potential Vanilloid 1, Antagonists.

Article Info: Received 18 June 2019; $\quad$ Review Completed 20 August 2019; $\quad$ Accepted 23 August 2019; $\quad$ Available online 25 August 2019

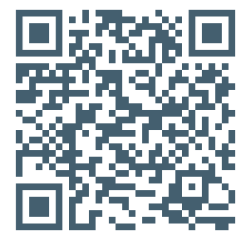

Cite this article as:

Ambatkar MP, Khedekar PB, Quinoline as TRPV1 Antagonists: A New Approach against Inflammation, Journal of Drug Delivery and Therapeutics. 2019; 9(4-s):782-788 http://dx.doi.org/10.22270/jddt.v9i4-s.3414

\section{*Address for Correspondence:}

\section{INTRODUCTION}

Inflammation, the first response of the immune system to harmful stimuli such as infection or irritation, consists of a cascade of biochemical events that propagates and matures the inflammatory response. ${ }^{1}$ It is a protective attempt by the organism to remove the injurious stimuli and initiate the healing process. However, if uncontrolled, inflammation can lead to a diverse array of acute, chronic and systemic inflammatory disorders. ${ }^{2-4}$

Usually, during acute inflammatory responses, cellular and molecular events and interactions efficiently minimize impending injury or infection. This mitigation process contributes to restoration of tissue homeostasis and resolution of the acute inflammation. However, uncontrolled acute inflammation may become chronic, contributing to a variety of chronic inflammatory diseases. ${ }^{5}$

At tissue level, inflammation is characterized by redness, swelling, heat, pain, and loss of tissue function, which result from local immune, vascular and inflammatory cell responses to infection or injury. ${ }^{6}$ Important microcirculatory events that occur during the inflammatory process include vascular permeability changes, leukocyte recruitment and accumulation, and inflammatory mediator release. ${ }^{7}$ Various pathogenic factors, such as infection, tissue injury, or cardiac infarction, can induce inflammation by causing tissue damage. The etiologies of inflammation can be infectious or non-infectious. In response to tissue injury, the body initiates a chemical signaling cascade that stimulates responses aimed at healing affected tissues. These signals activate leukocyte chemotaxis from the general circulation to sites of damage. These activated leukocytes produce cytokines that induce inflammatory responses. ${ }^{8}$

\section{Quinolines act as anti-inflammatory agents}

Quinoline is heterocyclic aromatic organic compound containing nitrogen and was first isolated in 1834 by Runge from coal tar and he named it as Leukol. Later in 1842, Gerhardt isolated it by heating the alkaloid cinchonine with alkali and named as quinoline. ${ }^{9}$ These heterocycles have been of considerable interest because a large number of natural products and drugs contain this heterocyclic unit. 10

Quinolines have attracted particular attention owing to their diverse array of pharmacological properties including the ability to target several causes of inflammation including transient receptor potential vanilloid 1 (TRPV1) antagonists. ${ }^{1}$ Several reviews have appeared on the 
anticancer or antitumor ${ }^{11,12}$, antimalarial ${ }^{13}$ and antimicrobial activities $^{14}$ of quinolines. This review will focus on targets of inflammation that is transient receptor potential vanilloid 1 followed by the quinoline-based modulators which acts as TRPV1 antagonists.

\section{Transient Receptor Potential (TRP) Family}

The transient receptor potential (TRP) superfamily is one of the largest families of ion channels and comprises 28 members. ${ }^{15,16}$ Based on amino acid sequence homology, the mammalian members of TRP channel family have been classified into six subfamilies: TRPC (Canonical), TRPV (Vanilloid), TRPM (Melastatin), TRPP (Polycystin), TRPML (Mucolipin) and TRPA (Ankyrin). The TRPV subfamily consists of a group of four channels, TRPV1, TRPV2, TRPV3 and TRPV4 that are critically involved in nociception and thermosensing, and two additional channels TRPV5 and TRPV6 that appear to be constitutively active and have been proposed to play a role in vitamin D dependant calcium uptake in the kidney and intestine respectively. ${ }^{17,18}$

\section{Targeting TRPV1: Vanilloid receptor antagonists}

The TRPV1 receptors, found in the peripheral and central nervous systems, are involved in the transmission and modulation of pain, as well as the integration of diverse painful stimuli. This receptor channel is activated by protons $\left(\mathrm{pH} 5\right.$, chemical stimuli), heat $\left(>42{ }^{\circ} \mathrm{C}\right.$, physical stimuli), endogeneous substances (such as endocannabinoid anandamide, lipoxygenase and arachidonic acid metabolites) and also by some natural ligands (such as capsaicin, other vanilloids and resiniferatoxin). This results in $\mathrm{Ca}^{2+}$ influx into the cells through the channel pore, causing cell membrane depolarisation and excitation of primary sensory neurons. It then transmits noxious nerve impulses to the spinal cord and finally delivers the perception of pain.1,19 Upon continued stimulation from any external stimuli the activity of neurotransmitters is depleted causing selective damage of the nerves and, thereby, results in desensitisation to further stimuli. As a result, TRPV1 receptors lose sensitivity to painful stimuli. Various TRPV1 agonists were used to treat pains (e.g. capsaicin, resiniferatoxin, etc.). However, several adverse side effects like burning sensation, irritation and neurotoxicity that were associated with this approach shifted the focus toward the discovery of TRPV1 antagonists. These antagonists block the pain signalling pathway with potentially fewer side effects. ${ }^{20-22}$

TRPV1 has been shown to be important in both nociception (the perception of pain) and the inflammatory responses. ${ }^{23,24}$ It is considered to be a highly validated target for pain, and both agonists and antagonists of TRPV1 are being evaluated as potential analgesics in clinical trials. Simply, its antagonists block the function of TRPV1 and relieve pain behaviours caused by inflammation, osteoarthritis and cancer in rodent models. Its agonists, such as capsaicin, cause desensitization of TRPV1 channels that relieves pain behaviours in preclinical species. ${ }^{25,26}$ The initial drug discovery research targeting TRPV1 was mainly focused on agonists; a dermal capsaicin patch is already on market for long-term treatment for neuropathic pain. ${ }^{27,28}$ However, most of the agonists have initial burning effects making their therapies complicated, and therefore, more focused consideration has been given to the antagonists for developing novel analgesic drugs. ${ }^{29}$

The first reported TRPV1 antagonist, capsazepine, was discovered by chemical modification from capsaicin. The amide bond of capsaicin was replaced by a thiourea group, and the amide nitrogen being a part of a bicyclic ring to form an orthogonal orientation with respect to the thiourea bond. Unfortunately, it was not a candidate for clinical use due to its low metabolic stability, poor pharmacokinetic properties and nonselectivity to other channels. ${ }^{28}$ Using this scaffold as a template, small molecule TRPV1 antagonists with various chemotypes have been discovered over the years. ${ }^{30-33}$ The classical TRPV1 ligands share three functional regions that act as pharmacophores (Figure 1) ${ }^{23}$ : i) an aromatic group (A-region), which mimics the vanilloid moiety of capsaicin; ii) a linker (B-region) such as ester, amide, urea and thiourea; and iii) an aliphatic group (C-region), which corresponds to a lipophilic octanyl moiety of capsaicin.



Figure 1. Pharmacophores of the representative TRPV1 ligands. For capsaicin, resiniferatoxin and capsazepine, three important pharmacophore regions are marked.

Nonclassical TRPV1 ligands have a carbonyl group, which is either present as a part of heterocyclic ring or is unrecognizable. ${ }^{23}$ The preclinical studies and clinical trials showed that the side effects such as hyperthermia and impaired noxious heat sensation (burn risk) are the main obstacles for developing TRPV1 antagonists.27 There has been a need to distinguish the excitatory effects and the analgesic effects of TRPV1, and it has been actively studied whether these side effects are on-target, that is, unavoidable, or can be mitigated by chemical modifications. ${ }^{34}$ Based on these efforts, second generation of TRPV1 antagonists that do not induce hyperthermia are under development 27 , and several compound series show promising results for overcoming these side effects.

This review focuses on the development of quinoline as TRPV1 antagonists with an emphasis on recent research in this field.

\section{Quinoline as TRPV1 Antagonist}

Many monosubstituted quinolines have been reported as TRPV1 antagonists. Compounds $\mathbf{1}$ and $\mathbf{2}$ were prepared by acylation of quinoline with 4(trifluoromethylthio)phenyl isocyanate. ${ }^{29}$ The activities of compounds were measured by a $\mathrm{Ca}^{2+}$ influx assay using human TRPV1 receptor. 35 The screening of compounds with single nitrogen containing bicyclic cores for their antagonistic activity at human TRPV1 revealed that the quinoline derivative 2 ( $\mathrm{IC}_{50}=420 \mathrm{nM}$ ) exhibited superior potency to the regioisomeric quinoline $\mathbf{1}\left(\mathrm{IC}_{50}=1500 \mathrm{nM}\right) .{ }^{29}$ 
<smiles>CC(C)(F)c1cccc(NC(=O)Nc2cccc3ncccc23)c1</smiles>

1

N-Aryl cinnamide 3 (AMG9810), identified independently through the screening studies at Amgen, was also found to be a highly selective TRPV1 receptor antagonist when profiled against more than 80 different drug targets. Compound $\mathbf{3}$ blocks the capsaicin-induced uptake of $\mathrm{Ca}^{2+}$ in TRPV1 expressing $\mathrm{CHO}$ cells with an $\mathrm{IC}_{50}$ value of $17 \mathrm{nM}$. Compound 3 was found to block TRPV1 activation by capsaicin as well as other agonists such as<smiles>CC(F)(F)c1cccc(NC(=O)Nc2cccc3cccnc23)c1</smiles>

2

acids and heat. ${ }^{15}$ SAR studies using $\mathbf{3}$ as a lead compound led to a series of $\mathrm{N}$-aryl cinnamide, the most potent of which were the quinolines $\mathbf{4 a}$ and $\mathbf{4 b}$ with $\mathrm{IC}_{50}$ values of 1.9 and $0.42 \mathrm{nM}$, respectively. These compounds exhibit good oral bioavailability in rats with $\mathrm{F}_{\text {oral }}=39 \%$ and $17 \%$, respectively, compared to negligible oral bioavailability $\left(\mathrm{F}_{\text {oral }}=3 \%\right)$ observed for the lead $\mathbf{3} .^{36}$<smiles>CC(C)(C)c1ccc(/C=C/C(=O)Nc2ccc3c(c2)OCCO3)cc1</smiles>

3<smiles>[X]CCN(CC[X])c1cc(C(F)(F)F)ccc1/C=C/C(=O)Nc1ccc2cccnc2c1</smiles>

4

$$
\mathbf{a X}=\mathrm{O} \quad \mathbf{b} \mathrm{X}=\mathrm{CH}_{2}
$$

SAR studies around HTS hit $\mathbf{5}$ led to the identification of the $\mathrm{N}$-quinolin-7-yl-6-phenylnicotinamide $\mathbf{6}$ which was identified as a potent TRPV1 antagonist with activity in an in vivo model of inflammatory pain. ${ }^{37}$<smiles>CN1CCCc2c(NC(=O)c3ccc(-c4ccccc4)cc3)cccc21</smiles>

5

This compound possessed excellent potency at human and rat TRPV1 receptors and a favourable in vitro DMPK profile. However, the low intrinsic clearance observed in liver microsomes [CLi 3.1 (human), 2.2 (rat), 3.9 (guinea $\mathrm{pig}) \mathrm{mL} / \mathrm{min} / \mathrm{g}$ tissue] did not translate into acceptable in vivo stability in the rat $\left(\mathrm{CL}_{\mathrm{b}} 33 \mathrm{~mL} / \mathrm{min} / \mathrm{kg}, \mathrm{T}_{1 / 2} 0.36 \mathrm{~h}\right.$ at 1 $\mathrm{mg} / \mathrm{kg}$ iv). Furthermore, compound 6 showed only modest activity in the guinea pig model of Freunds Complete Adjuvant (FCA)-induced inflammatory pain and was less efficacious than expected based on its high level of in vitro potency. Further optimisation of this lead series targeting, in<smiles>O=C(Nc1ccc2cccnc2c1)c1ccc(-c2ccccc2)nc1</smiles>

6

particular, an improved in vivo profile. This work has resulted in the identification of a compound which showed excellent levels of activity in the guinea pig FCA model on oral dosing. Initial efforts focused on modification of the terminal phenyl ring of $\mathbf{6}$. Substituted analogues $\mathbf{7}$ and $\mathbf{8}$ were prepared from methyl 6-chloronicotinate and the appropriate boronic acid using Suzuki-Miyaura coupling conditions ${ }^{38}$ followed by hydrolysis and standard EDCImediated amide coupling. Alternatively, compounds 9 - 12 were prepared directly from chloro-nicotinamide. ${ }^{37}$<smiles>[R]c1ccc(C(=O)Nc2ccc3cccnc3c2)cn1</smiles>

13-14 
As illustrated in Table 137 , the introduction of a fluoro-substituent into the 2- or 3-positions, $\mathbf{7}$ and $\mathbf{8}$, was well tolerated giving compounds with potency similar to that of the unsubstituted parent $\mathbf{6}$. The 4-fluoro substituted compound 9 showed $\sim 3$-fold lower potency at TRPV1 with $\mathrm{pKb} 8.2$ but following determination of in vitro ADME properties it was found that this compound possessed the best overall in vitro profile in this series with an acceptable P450 inhibition profile $\left(\mathrm{IC}_{50}>10 \mu \mathrm{M}\right.$ at five major human isoforms), and low intrinsic clearance in human and rat liver microsomes [CLi 1.7 (human), 1.1 (rat) $\mathrm{mL} / \mathrm{min} / \mathrm{g}$ tissue]. However, in guinea pig microsomes, 9 proved to be a highclearance compound ( $\mathrm{CLi} 42 \mathrm{~mL} / \mathrm{min} / \mathrm{g}$ ). Replacement of $4-\mathrm{F}$ with $4-\mathrm{Cl}, 4-\mathrm{CF}_{3}$ or $4-\mathrm{CN} \mathbf{1 0 - 1 2}$ was detrimental to potency and complete replacement of the terminal phenyl ring with smaller groups such as cyano $\mathbf{1 3}$ or chloro $\mathbf{1 4}$ also resulted in reduced levels of TRPV1 antagonist activity.

Table 1: Antagonist activity of nicotinamide derivatives 6 and 7-14 at human TRPV1 expressed in a 1321N1 cell line 40 against capsaicin in FLIPR (Fluorescence Imaging Plate Reader) assay

\begin{tabular}{|c|c|c|}
\hline Compound & $\mathrm{R}^{1}$ & hTRPV1 $^{\mathrm{a}} \mathrm{pK}_{\mathrm{b}}$ \\
\hline 6 & $\mathrm{Ph}$ & 8.7 \\
\hline 7 & $2-\mathrm{FPh}$ & 8.7 \\
\hline 8 & $3-\mathrm{FPh}$ & 8.6 \\
\hline 9 & $4-\mathrm{FPh}$ & 8.2 \\
\hline 10 & $4-\mathrm{ClPh}$ & 7.8 \\
\hline 11 & $4-\mathrm{CF} 3 \mathrm{Ph}$ & 7.3 \\
\hline 12 & $4-\mathrm{CNPh}$ & $<6.6$ \\
\hline 13 & $4-\mathrm{CN}$ & $<6.7$ \\
\hline 14 & $4-\mathrm{Cl}$ & $<6.7$ \\
\hline
\end{tabular}

a Standard error of mean (SEM) for all $\mathrm{pKb}$ values $\leq 0.1$

To investigate the effect of altering the conformation around the biaryl amide linker, the 2- and 4methylnicotinamide analogues 15, 16 and 17 were prepared.

Interestingly, it was found that the presence of a methyl in the 2-position was beneficial to TRPV1 antagonist potency, compounds 15 and 16, whereas the 4methylnicotinamide $\mathbf{1 7}$ was much less active (Table 2) ${ }^{37}$.<smiles>O[C@@H]1CCc2cccc(Nc3nc4cnc5ccccc5c4o3)c2C1</smiles>

18<smiles>O[C@@H]1CCc2cccc(Nc3nc4cnc5ccc(F)cc5c4o3)c2C1</smiles>

19<smiles>[R]c1ccc(-c2cc([R2])c(C(=O)Nc3ccc4cccnc4c3)c([R])n2)cc1</smiles>

15-17

Table 2: Antagonist activity of methylnicotinamide derivatives at human TRPV1 expressed in a 1321N1 cell line $^{40}$ against capsaicin in FLIPR (Fluorescence Imaging Plate Reader) assay

\begin{tabular}{|c|c|c|c|c|}
\hline Compound & $\mathrm{R}^{1}$ & $\mathrm{R}^{2}$ & $\mathrm{R}^{3}$ & hTRPV1 $^{\mathrm{a}} \mathrm{pK}_{\mathrm{b}}$ \\
\hline 15 & $\mathrm{Me}$ & $\mathrm{H}$ & $\mathrm{H}$ & 9.0 \\
\hline 16 & $\mathrm{Me}$ & $\mathrm{H}$ & $\mathrm{F}$ & 8.5 \\
\hline 17 & $\mathrm{H}$ & $\mathrm{Me}$ & $\mathrm{H}$ & 6.7 \\
\hline
\end{tabular}

a $\mathrm{SEM} \leq 0.1$ for 15 and $16, \mathrm{SEM}=0.3$ for 17

The reduced potency seen with $\mathbf{1 7}$ may be due to the 4-methyl group causing a conformational change resulting in the pyridyl nitrogen in $\mathbf{1 7}$ occupying an alternative and less favourable position in the active site when compared to the 2-methyl analogue $\mathbf{1 5}$ and unsubstituted analogue 6 . The 2-methylnicotinamide 16 was tested in a guinea pig model of FCA induced inflammatory pain $^{39}$ and showed $42 \%$ reversal of hyperalgesia at a dose of $5 \mathrm{mg} / \mathrm{kg}$ ip. Although this represented a significant improvement over the activity of $\mathbf{6}$ in the same in vivo model (32\% reversal at $30 \mathrm{mg} / \mathrm{kg} \mathrm{sc}$ ).

An efficient synthesis of 2-amino-oxazolo[4,5c]quinoline TRPV1 antagonists is described via a thiourea formation/carbodiimide cyclization sequence. Synthetic route optimization eliminates intermediate isolations and facilitates the rapid preparation of a series of novel pentacyclic TRPV1 antagonists 18-24. From this series, compound 22 was identified as a potent and selective TRPV1 antagonists with hTRPV1 $\mathrm{IC}_{50}=5 \mathrm{nM}$ and $>100$-fold selectivity versus other TRP channels. ${ }^{41}$<smiles>O[C@@H]1CCc2cccc(Nc3nc4cnc5cc(F)ccc5c4o3)c2C1</smiles>

20<smiles>OC1CCc2cccc(Nc3nc4cnc5cc(Cl)ccc5c4o3)c2C1</smiles>

21<smiles>O[C@H]1CCc2cccc(Nc3nc4cnc5cc(C(F)(F)F)ccc5c4o3)c2C1</smiles>

22<smiles>O[C@H]1CCc2cccc(Nc3nc4cnc5ccc(C(F)(F)F)cc5c4o3)c2C1</smiles>

23<smiles>O[C@H]1CCc2cccc(Nc3nc4cnc5c(C(F)(F)F)cccc5c4o3)c2C1</smiles>

24 
Many monosubstituted quinolines have been reported as TRPV1 antagonists. ${ }^{1}$ One such report identified quinoline derivatives $\mathbf{2 5}$ and $\mathbf{2 6}$ possessing oral bioavailability in rats ( $F=39 \%$ and $17 \%$, respectively) as promising agents in the capsaicin (CAP) mediated functional<smiles>O=C(/C=C/c1ccc(C(F)(F)F)nc1N1CCOCC1)Nc1ccc2cccnc2c1</smiles>

25

SAR on a series of conformationally constrained analogues of the cis conformer of compounds 25 and 26 identified 7-oxo and 8-oxoquinoline derivatives 27 and 28 as TRPV1 antagonists. Compound $\mathbf{2 7}$ was orally bioavailable ( $F=31 \%$ in rats) and showed potent antagonism against rat TRPV1 [rTRPV1 (CAP) IC $50=7.4 \mathrm{nM}$ and rTRPV1 (acid) $\mathrm{IC}_{50}$ $=8.0 \mathrm{nM}$ ] and human TRPV1 [hTRPV1 (CAP) IC $50=3.7 \mathrm{nM}$ and hTRPV1 (acid) IC50 $=4.2 \mathrm{nM}$ ] in CAP and acid-mediated assays. ${ }^{36}$ It also blocked TRPV1-mediated physiological response in the CAP-induced hypothermia model in rats.<smiles>FC(F)(F)c1ccc(-c2cc(Oc3ccc4cccnc4c3)ncn2)cc1</smiles>

27

A quinoline carboxamide derivative 29 with $\mathrm{N}$ methyl substitution showed moderate activities against hTRPV1 $(\mathrm{pKb}=6.5)$ with capsaicin as the agonist. ${ }^{44}$ Optimisation of $\mathbf{2 9}$ led to the development of compound $\mathbf{3 0}$ with a carboxamide at the 7-position and no substitution on the quinoline nitrogen. Compound $\mathbf{3 0}$ exhibited good levels of in vitro metabolic stability ( $\mathrm{CLi}_{\mathrm{i}}<5 \mathrm{ml} / \mathrm{min} / \mathrm{g}$ liver) in human, rat, guinea pig and dog liver microsomes and also $\mathrm{P} 450$ inhibition with $\mathrm{IC}_{50}$ values $>18 \mu \mathrm{M}$ at five major human isoforms (1A2, 2C9, 2C19, 2D6 and 3A4). It also showed excellent potency against hTRPV1 $\left[\mathrm{pIC}_{50}(\mathrm{acid})=8.1\right]$ and rTRPV1 receptors $\left[\mathrm{pIC}_{50}\right.$ (acid) $\left.=7.6\right] .{ }^{44}$ Overall, quinolines with carboxamide substitution and 8-oxo-substituted quinolines showed promising TRPV1 antagonism. ${ }^{1}$ assay ( $\mathrm{IC}_{50}=1.9$ and $0.42 \mathrm{nM}$, respectively) and the $\mathrm{pH}$ mediated assay ( $\mathrm{IC}_{50}=1.3$ and $1.0 \mathrm{nM}$, respectively). The maximum plasma concentrations for $\mathbf{2 5}$ and $\mathbf{2 6}$ were $\mathrm{C}_{\max }=$ $540 \mathrm{ng} / \mathrm{ml}$ and $320 \mathrm{ng} / \mathrm{ml}$ at $5 \mathrm{mg} / \mathrm{kg}$ p.o., respectively. ${ }^{36}$<smiles>O=C(/C=C/c1ccc(C(F)(F)F)nc1N1CCCCC1)Nc1ccc2cccnc2c1</smiles>

26

However, it was inefficacious at preventing thermal hyperalgesia generated by complete Freund's adjuvant in rats. 42 Therefore, to improve the potency and pharmacokinetic $(\mathrm{PK})$ properties of 27 , the 8-oxoquinoline derivative 28 [rTRPV1 (CAP) IC $_{50}=15 \mathrm{nM}$ ] was designed with an encouraging microsomal stability. 43 Compound 28 was cleared at the rate of 44 and $135 \mathrm{ml} / \mathrm{min} / \mathrm{mg}$ in rat and human, respectively, compared with 111 and 250 $\mathrm{ml} / \mathrm{min} / \mathrm{mg}$ for compound 27.<smiles>FC(F)(F)c1ccc(-c2cc(Oc3cccc4cccnc34)ncn2)cc1</smiles>

28

Trisubstituted tetrahydroquinoline urea $\mathbf{3 1}$ has been reported as a TRPV1 antagonist in human TRPV1 calcium influx assay and an inhibitor of CYP3A4 enzyme (hTRPV1 IC $_{50}=7 \mathrm{nM}$ and $47 \%$ CYP3A4 inhibition at 10 $\mu \mathrm{M}) .45$ Another compound, $\mathbf{3 2}$ with 5,5 diphenyl pentadienamide moiety at the 4- position was also reported as a TRPV1 antagonist. ${ }^{46}$ The (R)-enantiomer of $\mathbf{3 2}$ (hTRPV1 $\mathrm{IC}_{50}=0.14$ and rTRPV1 $0.35 \mathrm{nM}$ ) was more potent than the (S)-32 in the capsaicin-based assay and showed good PK profile in rats, dogs and monkeys. The (R)-32 was effective at preventing mechanical allodynia in rats in a dose dependent manner and reversed thermal hyperalgesia in a model of neuropathic pain induced by sciatic nerve injury. ${ }^{46}$<smiles>O=C(Nc1ccc2cccnc2c1)c1ccc(-c2ccccc2)nc1</smiles>

30<smiles>CC(C)Oc1ccc(/C(=C\C=C\C(=O)Nc2cccc3c2C[C@@H](O)C(=O)N3)c2ccc(C(F)(F)F)cc2)cc1</smiles>

32 


\section{CONCLUSION}

From all above the information, it is cleared that the heterocyclic moiety quinolines have importance in searching the safe and effective next generation anti-inflammatory drugs. This is explained by the discovery of various quinoline derivatives as TRPV1 receptor antagonists and the activities of these derivatives depend on the nature and position of substituents present on the quinoline ring or compounds containing a quinoline ring fused to other heterocyclic compounds. Overall, the quinoline moiety can be used as a new template for designing and identifying the novel anti-inflammatory drugs to treat the diseases associated with inflammation in future.

\section{REFERENCES}

1. Mukherjee S, Pal M, Quinoline: A new hope against inflammation, Drug Discovery Today, 2013; 18: 389-398.

2. Chen L, Deng H, Cui H, Fang J, Zuo Z, Deng J, Li Y, Wang X, Zhao L, Inflammatory responses and inflammation associated diseases in organs, Oncotarget, 2018; 9(6): 7204-7218.

3. Libby P, Atherosclerosis: the new view, Scientific American, 2002; 286: 46-55.

4. Hansson GK, Libby $P$, The immune response in atherosclerosis: a double-edged sword, Nature Reviews Immunology, 2006; 6: 508-519.

5. Zhou Y, Hong Y, Huang H, Triptolide Attenuates Inflammatory Response in Membranous Glomerulo-Nephritis Rat via Downregulation of NF- $\kappa \mathrm{B}$ Signaling Pathway, Kidney and Blood Pressure Research, 2016; 41: 901-910.

6. Takeuchi 0, Akira S, Pattern Recognition Receptors and Inflammation, Cell 2010; 140: 805-820.

7. Ferrero-Miliani L, Nielsen O, Andersen P, Girardin S, Chronic inflammation: importance of NOD2 and NALP3 in interleukin$1 \beta$ generation, Clinical and Experimental Immunology, 2007; 147: 227-235.

8. Chertov O, Yang D, Howard O, Oppenheim JJ, Leukocyte granule proteins mobilize innate host defences and adaptive immune responses, Immunology Reviews, 2000; 177: 68-78.

9. Manske RH, Review: The Chemistry of Quinolines, Chemical Review, 1942; 30(1): 113-144.

10. Pandeya SN, Tyagi A, Synthetic Approaches for Quinoline And Isoquinoline, International Journal of Pharmacy and Pharmaceutical Sciences, 2011; 3: 53-61.

11. Solomon VR, Lee $H$, Quinoline as a privileged scaffold in cancer drug discovery, Current Medicinal Chemistry, 2001; 18: $1488-1508$.

12. Vezmar M, Georges E, Reversal of MRP-mediated doxorubicin resistance with quinoline-based drugs. Biochemical Pharmacology, 2001; 59: 1245-1252.

13. Jain R, Kaur K, Jain M, Reddy RP, Quinolines and structurally related heterocycles as antimalarials. European Journal of Medicinal Chemistry, 2010; 45: 3245-3264.

14. Neu HC, Quinolone antimicrobial agents, Annual Review of Medicine, 1992; 43: 465-486.

15. Korlipara VL, Transient Receptor Potential Vanilloid 1 Channel Modulation: A Novel Approach to Pain therapy, Current Bioactive Compounds, 2008; 4: 110-25.

16. Vennekens $\mathrm{R}$, Owsianik G, Nilius $\mathrm{B}$, Vanilloid transient receptor potential cation channels: An overview, Current Pharmaceutical Design, 2008; 14: 18-31.

17. Szallasi A, Cortright DN, Blum CA, Eid SR, The vanilloid receptor TRPV1: 10 years from channel cloning to antagonist proof-of-concept, Nature Reviews Drug Discovery, 2007; 6: 357-372.

18. Pedersen SF, Owsianik G, Nilius B, TRP channels: An overview, Cell Calcium, 2005; 38: 233-252.

19. Caterina MJ, Julius D, The vanilloid receptor: a molecular gateway to the pain pathway, Annual Review of Neuroscience, 2001; 24: 487-517.

20. Davis JB, Gray J, Gunthorpe MJ, Hatcher JP, Davey PT, Overend P, Harries MH, Latcham J, Clapham C, Atkinson K, Hughes SA, Rance K, Grau E, Harper AJ, Pugh PL, Rogers DC, Bingham, Randall A, Sheardown SA, Vanilloid receptor-1 is essential for inflammatory thermal hyperalgesia, Nature, 2000; 405(6783):183-187.
21. Caterina MJ, Leffler A, Malmberg AB, Martin WJ, Trafton J, Petersen-Zeitz KR, Koltzenburg M, Basbaum AI, Julius D, Impaired nociception and pain sensation in mice lacking the capsaicin receptor, Science 2000; 288: 306-313.

22. Pal M, Angaru S, Kodimuthali A, Dhingra N, Vanilloid receptor antagonists: emerging class of novel anti-inflammatory agents for pain management, Current Pharmaceutical Design, 2009; 15: 1008-1026.

23. Lee $Y$, Hong S, Cui M, Sharma PK, Lee J, Choi, Transient receptor potential vanilloid type 1 antagonists: a patent review (2011-2014), Expert Opinion on Therapeutic Patents, 2015; 25(3): 291-318.

24. Conway SJ, TRPing the switch on pain: an introduction to the chemistry and biology of capsaicin and TRPV1, Chemical Society Reviews, 2008; 37: 1530-1545.

25. Wong GY, Gavva NR, Therapeutic potential of vanilloid receptor TRPV1 agonists and antagonists as analgesics: recent advances and setbacks, Brain Research Reviews, 2009; 60: 267-277.

26. Westaway SM, The potential of transient receptor potential vanilloid type 1 channel modulators for the treatment of pain, Journal of Medicinal Chemstry, 2007; 50: 2589-2596.

27. Szolcsanyi J, Sandor Z, Multisteric TRPV1 nocisensor: a target for analgesics, Trends in Pharmacological Sciences, 2012; 33: 646-655.

28. Brito R, Sheth S, Mukherjea D, Rybak L, Ramkumar V, TRPV1: a potential drug target for treating various diseases, Cells, 2014; 3: 517-545.

29. Gomtsyan A, Bayburt EK, Schmidt RG, Zheng GZ, Perner RJ, Didomenico S, Koenig JR, Turner S, Jinkerson T, Drizin I, Hannick SM, Macri BS, McDonald HA, Honore Prisca, Wismer CT, Marsh KC, Wetter J, Stewart KD, Oie T, Jarvis MF, Surowy $\mathrm{CS}$, Faltynek CR, Lee $\mathrm{CH}$, Novel transient receptor potential vanilloid 1 receptor antagonists for the treatment of pain: structure-activity relationships for ureas with quinoline, isoquinoline, quinazoline, phthalazine, quinoxaline, and cinnoline moieties, Journal of Medicinal Chemistry, 2005; 48: 744-752.

30. Plowright AT, Johnstone C, Kihlberg J, Pettersson J, Robb G, Thompson RA, Hypothesis driven drug design: improving quality and effectiveness of the design-make-test-analyse cycle, Drug Discovery Today, 2012; 17: 56-62.

31. Kort ME, Kym PR, TRPV1 antagonists: clinical setbacks and prospects for future development, Progress in Medicinal Chemistry, 2012; 51: 57-70.

32. Voight EA, Kort ME, Transient receptor potential vanilloid-1 antagonists: a survey of recent patent literature, Expert Opinion on Therapeutic Patents, 2010; 20: 1107-1122.

33. Xia R, Samad TA, Btesh J, Jiang LH, Kays I, Stjernborg L, Dekker $\mathrm{N}$, TRPV1 signaling: mechanistic understanding and therapeutic potential, Current Topics in Medicinal Chemistry, 2011; $11: 2180-2191$.

34. Szallasi A, Sheta M, Targeting TRPV1 for pain relief: limits, losers and laurels, Expert Opinion on Investigational Drugs, 2012; 21: 1351-1369.

35. Zicha S, Radresa O, Laplante P, Morton M, Jones K, Main M, Trivedi S, Julien RP, Griffin A, Labrecque J, Ahmad S, Brown W, Novel Methodology to Identify TRPV1 Antagonists Independent of Capsaicin Activation, Journal of Biomolecular Screening, 2012; 18(5): 544-555.

36. Doherty EM, Fotsch C, Bo Y, Chakrabarti PP, Chen N, Gavva N, Han N, Kelly MG, Kincaid J, Klionsky L, Liu Q, Ognyanov VI, Tamir R, Wang X, Zhu J, Norman MH, Treanor JJS, Discovery of potent, orally available vanilloid receptor-1 antagonists. Structure-activity relationship of $\mathrm{N}$-aryl cinnamides, Journal of Medicinal Chemistry, 2005; 48: 71-90.

37. Westaway SM, Thompson M, Rami HK, Stemp G, Throuw LS, Mitchell DJ, Seal JT, Medhurst SJ, Lappin SC, Biggs J, Wright J, Arpino S, Jermann JC, Cryan JE, Holland V, Winborn KY, Coleman T, Stevens AJ, Davis JB, Gunthorpe MJ, Design and synthesis of 6-phenylnicotinamide derivatives as antagonists of TRPV1, Bioorganic and Medicinal Chemistry Letters, 2008; 18: $5609-5613$.

38. Miyaura N, Suzuki A, Chemical Reviews, 1995; 95: 2457.

39. Walker KM, Urban L, Medhurst SJ, Patel S, Panesar M, Fox AJ McIntyre P, The VR1 antagonist capsazepine reverses mechanical hyperalgesia in models of inflammatory and 
neuropathic pain, Journal of Pharmacology and Experimental Therapeutics, 2003, 304(1), 56-62.

40. Gunthorpe MJ, Rami HK, Jerman JC, Smart D, Gill CH, Soffin EM, Luis HS, Lappin SC, Egerton J, Smith GD, Worby A, Howett L, Owen D, Nasir S, Davies CH, Thompson M, Wyman PA, Randall AD, Davis JB, Identification and characterization of SB-366791, a potent and selective vanilloid receptor (VR1/TRPV1) antagonist, Neuropharmacology, 2004; 46: 133-149.

41. Voight EA, Daanen JF, Kort ME, Synthesis of Oxazolo[4,5c]quinoline TRPV1 antagonists, Journal of Organic Chemistry, 2010; 75: 8713-8715.

42. Norman MH, Zhu J, Fotsch C, Bo Y, Chen N, Chakrabarti P, Doherty EM, Gavva NR, Nishi,ura N, Nixey T, Ognyanov VI, Rzasa RM, Stec M, Surapaneni S, Tamir R, Viswanandhan VN, Treanor JJS, Novel vanilloid receptor-1 antagonists: 1. Conformationally restricted analogues of trans-cinnamides, Journal of Medicinal Chemistry, 2007; 50(15): 3497-3514.

43. Doherty EM, Fotsch C, Bannon AW, Bo Y, Chen N, Dominguez C, Falsey J, Gavva NR, Katon J, Nixey T, Ognyanov VI, Pettus L, Rzasa RM, Stec M, Surapaneni S, Tamir R, Zhu J, Treanor JJS,
Norman MH, Novel vanilloid receptor-1 antagonists: 2 . Structure- activity relationships of 4-oxopyrimidines leading to the selection of a clinical candidate, Journal of Medicinal Chemistry, 2007; 50(15): 3515-3527.

44. Westaway SM, Chung YK, Davis JB, Holland V, Jerman JC, Medhurst SJ, Rami HK, Stemp G, Stevens AJ, Thompson M, Winborn KY, Wright J, N-tetrahydroquinolinyl, N-quinolinyl and $\mathrm{N}$-isoquinolinyl biaryl carboxamides as antagonists of TRPV1, Bioorganic and Medicinal Chemistry Letters, 2006; 16: 4533-4536.

45. Schmidt RG, Bayburt EK, Latshaw SP, Koenig JR, Daanen JF, McDonald HA, Bianchi BR, Zong C, Joshi S, Honore P, Marsh $\mathrm{KC}$, Lee $\mathrm{CH}$, Faltynek CR, Gomtsyan A, Chroman and tetrahydroquinoline ureas as potent TRPV1 antagonists, Bioorganic and Medicinal Chemistry Letters, 2011; 21: 13381341.

46. Saku O, Ishida H, Atsumi E, Sugimoto Y, Kodaira H, Kato Y, Shirakura S, Nakasato $Y$, Discovery of novel 5,5diarylpentadienamides as orally available transient receptor potential vanilloid 1 (TRPV1) antagonists, Journal of Medicinal Chemistry, 2012; 55: 3436-3451. 